\title{
Awareness, knowledge, attitude and use of social media among librarians and in libraries of medical colleges of punjab: A study
}

\author{
Shinderpal Kaur ${ }^{1}$, Rajeev Manhas, ${ }^{2, *}$ \\ ${ }^{1}$ Research Scholar, ${ }^{2}$ Chief Librarian, ${ }^{1}$ DLIS, Desh Bhagat University, Mandi Gobindgarh, Punjab, ${ }^{2}$ Baba Farid University of Health \\ Science, Faridkot, Punjab, India
}

*Corresponding Author: Rajeev Manhas

Email: dr.rajeevmanhas@gmail.com

\begin{abstract}
Introduction: Social media is becoming an essential part of today's life. Even, it is hard to imagine a daily routine without social media. Libraries are the main source of creating; gathering and sharing knowledge and librarians are the information managers, and an important link creator in between a user and library resources. Social media is so powerful tool that it can disseminate a piece of information to any number of users in more secure and reliable way, thus social media can be used for delivery of library services. The present study is an attempt to know the present status awareness, knowledge and attitude of medical librarians about social media and its usage in delivery of library services.

Objectives: The main aim of the study is to know the level of awareness, knowledge and use of social media applications among librarians and in libraries of medical colleges of Punjab.

Method: A self-structured questionnaire was designed for the librarians to collect the relevant data from the medical colleges' libraries of Punjab under study. The investigator personally visited all the medical colleges under study for data collection.

Results: The results of study revealed that $75 \%$ of the librarians are aware of various applications of social media to be used for providing library services. $87.5 \%$ of the respondents i.e. librarians admitted that they are or will use social media applications for communication with users, followed by reference services with $75 \%$ responses. A majority of the respondents from libraries of medical colleges are not satisfied with the present infrastructure available for access of social media with $75 \%$ responses. $50 \%$ of the librarians indicated poor infrastructure as one of the major reason for dissatisfaction, followed by lack of training/ skills with $37.5 \%$ responses.
\end{abstract}

Keywords: Social media, Medical librarians, Case study, Medical colleges, Punjab, Awareness, Attitude, Knowledge.

\section{Introduction}

Social media is considered as the major tool for sharing of information in this information based society. It is now becoming an integral part of daily routine of the people. The features of social media are so powerful that a user feels like interacting with other similarly as face-to-face interactions with each other. The social media applications are widely accepted in various fields and it is also making their way in the libraries. Libraries are the main source of creating, gathering and sharing knowledge. So, accordingly, the libraries should be up-dated in such a way that it should able to meet the requirements of present day's users and the social media is making this way very easy. Social media can be a powerful medium for delivery of desired information in an educational setup at the doorsteps or information accessing desks of research scholars, teachers and students.

\section{Review of literature}

Ahenkorah-Maefo and Akussah (2016) conducted a quantitative study entitled "Changing the face of reference and user services: Adoption of social media in top Ghanaian academic libraries". The main purpose of the study was to know response of academic librarians for use of social media in reference and user services. The study revealed that a majority of academic librarians were familiar with the use of social media for both personal and work-related purposes. The results further depicted that there is a lack of required skills to use social media as tool for delivery of library services. Agyekum, Beatric and Trivedi (2016) in their study on adoption of social networking tools in public university libraries in Ghana, found that librarians were aware of social networking and sometimes use LinkedIn, Twitter, Blogs, Wikis, Flickr, Slide Share, and YouTube. The respondents used social networking tools for dissemination of library news, library events, group discussion, general library information, sharing e-resources, and offering library resources. The study suggested that the libraries should be provided with Internet connectivity and other necessary tools to ensure proper functioning and effective usage of networking tools. Ayu and Abrizah (2011) conducted a study among Malaysian academic libraries to know the use of Face book as a social networking for providing library services to users. The study revealed that most of the libraries used Face book for marketing services and their advertisement. The major benefit of using Face book in academic libraries is that users can communicate with the libraries at any time. Butt, Qutab and Mohamad (2011) examined the 48 academic libraries (university and college), 21 special libraries, 5 public libraries and 1 school library in the city of Lahore. The results showed that the major problem in access and use of the Internet was the slow speed of the Internet faced by $48 \%$ libraries. The second major problem faced by $32 \%$ libraries was connection cutoff and $31 \%$ libraries faced the problem of shortage of funds. The staff members as well as users in $27 \%$ libraries were not aware of the advantages to use of Internet. The study showed that libraries under study had inadequate hardware facility, unavailability of support to 
maintain the Internet facility and limited time for users to access the Internet. Mansor and Idris (2010) conducted a study to find the level of awareness among librarians at the International Islamic University in Malaysia (IIUM). A selfstructured questionnaire was used to collect data from the respondents i.e. 46 librarians. The results of the study show that $33 \%$ of the respondents were not aware of social media applications being employed in libraries and on the other hand, $67 \%$ respondents admitted that they are fully aware about the applications of social media to be used for library services. Tripathi and Kumar (2010) conducted a study using survey method on use of social networks in libraries of higher education institutions. The investigator used the convenience sampling technique to collect data from 277 university libraries. The results of study show that social network has the capacity to improve library services to the users. The study put forward the suggestions for library and information science professionals to adopt social media for delivery of traditional services in an innovative manner to address the information requirements of the users of ICT based era.

\section{Research methodology}

The investigator used the questionnaire method for collection of data for the present study. A self-structured questionnaire was designed for purpose to collect data about the infrastructure available at the medical college libraries for access of social media application and the respondents for the same were librarians/in-charges of the college libraries under study. The Survey period was January to April 2018.

\section{Scope of the study}

The scope of the present study is limited to the libraries of the medical colleges of Punjab State affiliated to Baba Farid University of Health Sciences, Faridkot, Punjab (Annexure-I).

\section{Objectives}

The study was conducted to fulfill the following objectives.

1. To find out awareness of social media among medical college librarians.

2. To know the use of social media and e-resources in the libraries.

3. To study the impact of social media on library services and staff.

4. To explore librarians' satisfaction with the present status of social media support at libraries of medical colleges under study.

\section{Results and Discussion}

Table 1: Library with computers and internet connection facility

\begin{tabular}{|l|c|c|c|}
\hline Computers with internet connection facility & Yes (\%) & No (\%) & Total \% \\
\hline $\begin{array}{l}\text { Does your college library have computers and Internet connection } \\
\text { facility to access Internet, e-resources and social media applications? }\end{array}$ & 75 & 25 & 100 \\
\hline
\end{tabular}

Table 1 shows that out of 8 libraries of medical colleges, $6(75 \%)$ have computers with Internet connection facility to access the Internet services, e-resources and social media applications.

Table 2: Awareness about social media among librarians

\begin{tabular}{|l|c|c|c|}
\hline Awareness about social media among librarians & Yes (\%) & No (\%) & Total \% \\
\hline $\begin{array}{l}\text { Are you aware about the applications of social media in } \\
\text { library? }\end{array}$ & 75 & 25 & 100 \\
\hline
\end{tabular}

The librarians of medical colleges were asked to indicate their awareness about the social media applications in libraries and it can be inferred from the table 2 that $75 \%$ of the librarians are aware of various applications of social media to be used for providing library services, whereas $25 \%$ librarians are unaware of it. Ahenkorah-Maefo and Akussah (2016) also support the results that a majority of academic librarians were familiar with the use of social media for both personal and work-related purposes. Agyekum, Beatric and Trivedi (2016) in their study on adoption of social networking tools in public university libraries in Ghana, also found that librarians were aware of social. Mansor and Idris (2010) conducted a study to find the level of awareness among librarians at the International Islamic University in Malaysia (IIUM). A self-structured questionnaire was used to collect data from the respondents i.e. 46 librarians. The results of the study show that $33 \%$ of the respondents were not aware of social media applications being employed in libraries and on the other hand, 67\% respondents admitted that they are fully aware about the applications of social media to be used for library services.

Table 3: Types of e-resources subscribed in library

\begin{tabular}{|l|c|}
\hline Types of E-resources & \% \\
\hline Full text & 50 \\
\hline Abstracts & 25 \\
\hline Bibliographical & 12.5 \\
\hline Electronics access with print resources & 12.5 \\
\hline Total \% & 100 \\
\hline
\end{tabular}

The librarians were asked to indicate the various types of e-resources subscribed in their respective libraries and their availability for users. Table 3 shows that a majority of the libraries of medical colleges under study i.e. $50 \%$ have subscribed the full text e-resources, followed by $25 \%$ who 
subscribed abstracts based e-resources and $12.5 \%$ each have subscribed the bibliographical and electronic access along with print resources.

Table 4: Period of access available for users

\begin{tabular}{|c|c|}
\hline $\begin{array}{l}\text { No. of hours access of internet/ social media } \\
\text { available for users }\end{array}$ & $\mathbf{\%}$ \\
\hline Up to 8 hours & 25 \\
\hline $8-12$ hours & 12.5 \\
\hline More than 12 hours & 62.5 \\
\hline Total \% & 100 \\
\hline
\end{tabular}

Table 4 shows the opening hours of Internet section of medical college libraries under study. A majority of the medical colleges under study i.e. $62.5 \%$ are opened for more than 12 hours for access of Internet/ social media applications, followed by $25 \%$ upto 8 hours and $12.5 \%$ in between $8-12$ hours.

Table 5: Purposes of use of social media among librarians

\begin{tabular}{|l|c|}
\hline Purpose & \% \\
\hline Communication & 87.5 \\
\hline Marketing of library services & 37.5 \\
\hline Reference services & 75 \\
\hline Posting of resources review & 25 \\
\hline New arrivals information/ CAS & 25 \\
\hline Library News & 12.5 \\
\hline
\end{tabular}

The librarians of the medical college libraries were further asked to answer the question for what purposes they are using or will use social media applications in the library. Table 5 shows that $87.5 \%$ of the respondents i.e. librarians admitted that they are or will use social media applications for communication with users, followed by reference services with $75 \%$ responses. There are $37.5 \%$ of the respondents who admitted that they are using or will use for marketing of their library services, followed by posting of review and for providing the new arrivals information/ CAS options with $25 \%$ each responses. $12.5 \%$ also indicated that they are or will use it for sharing of library news among the users of medical college libraries.

Agyekum, Beatric and Trivedi (2016) found that librarians used social networking tools for dissemination of library news, library events, group discussion, general library information, sharing e-resources, and offering library resources. Ayu and Abrizah (2011) conducted a study among Malaysian academic libraries and the study revealed that most of the libraries used Face book for marketing their services and for advertisement. The major benefit of using Face book in academic libraries is that users can communicate with the libraries at any time.
Table 6: Frequency of average no. of daily visitors for access of social media

\begin{tabular}{|c|c|}
\hline $\begin{array}{l}\text { As per your opinion, how many average } \\
\text { numbers of users visit the library on daily } \\
\text { basis for access of social media applications? }\end{array}$ & \\
\hline Less than 50 & 50 \\
\hline $51-75$ & 25 \\
\hline $76-100$ & 12.5 \\
\hline More than 100 & 12.5 \\
\hline Total \% & 100 \\
\hline
\end{tabular}

It is evident from table 6 that $50 \%$ of the librarians are of opinion that less than 50 numbers of visitors on an average visit the library on daily basis to access the social media applications. $25 \%$ of respondents are of view that averagely upto 75 users visit the library for accessing the social media applications, followed by $12.5 \%$ each for 76 100 and more than 100 options.

Table 7: Impact of social media on library staff

\begin{tabular}{|l|c|}
\hline $\begin{array}{l}\text { As per your opinion, please indicate the } \\
\text { impact of social media applications on library } \\
\text { staff? }\end{array}$ & $\%$ \\
\hline Workload of staff will increase & 37.5 \\
\hline Training or skills to be upgraded & 25 \\
\hline Waste of time of library staff & 12.5 \\
\hline Circulation will decrease & 25 \\
\hline Total \% & 100 \\
\hline
\end{tabular}

Table 7 depicts that $37.5 \%$ of the librarians are of opinion that workload of staff will increase due to implementation of social media in libraries. There are $25 \%$ of the librarians, who are of the view that training and skills are required to be upgraded for proper implementation of social media in libraries and similar percentage of librarians agreed that circulation will be decreased due to social media adoption in library. $12.5 \%$ also found it as waste of time of library staff.

Table 8: Impact of social media on library staff

\begin{tabular}{|l|c|}
\hline $\begin{array}{l}\text { As per your opinion, please indicate the } \\
\text { impact of social media applications on library } \\
\text { services? }\end{array}$ & $\%$ \\
\hline Increase in use/ demand of e-resources & 25 \\
\hline Increase in demand of web based services & 25 \\
\hline Decrease in use of print resources & 12.5 \\
\hline Decrease of library visitors (physically) & 37.5 \\
\hline Total \% & 100 \\
\hline
\end{tabular}

Table 8 demonstrates that $37.5 \%$ of the librarians are of opinion that physical visitorship will be affected with the addition of social media tools in library, followed by increase in use of e-resources and web based services with $25 \%$ responses each. $12.5 \%$ of the respondents are also in opinion that use of print resources will decrease if the social media is used for delivery of library services. 
Table 9: Satisfaction with the present status of social media support at libraries

\begin{tabular}{|c|c|c|c|}
\hline 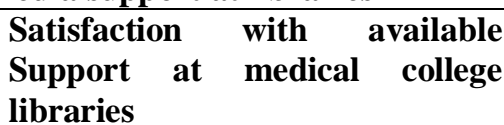 & $\begin{array}{l}\text { Yes } \\
(\%)\end{array}$ & $\begin{array}{l}\text { No } \\
(\%)\end{array}$ & $\begin{array}{c}\text { Total } \\
\%\end{array}$ \\
\hline $\begin{array}{l}\text { Are you satisfied with the present } \\
\text { status of social media } \\
\text { available at medical college } \\
\text { libraries? }\end{array}$ & 25 & 75 & 100 \\
\hline
\end{tabular}

Table 9 shows that a majority of the respondents from libraries of medical colleges are not satisfied with the present infrastructure available for access of social media with $75 \%$ responses and only $25 \%$ are satisfied with the present support of medical colleges toward social media.

Table 10: Reasons of dissatisfaction with the provision of social media at medical college libraries

\begin{tabular}{|l|c|}
\hline Reasons of dissatisfaction & \% \\
\hline Lack of technical manpower & 25 \\
\hline Lack of training/ skills & 37.5 \\
\hline Services to be based on charges & 12.5 \\
\hline Poor infrastructure & 50 \\
\hline
\end{tabular}

Librarians, who were not satisfied with the status of infrastructure for access of social media, were further asked to indicate the multiple reasons of dissatisfaction. Table 9 demonstrated the various reasons of dissatisfaction among the medical college librarians. $50 \%$ of the librarians indicated poor infrastructure as one of the major reason for dissatisfaction, followed by lack of training/ skills with $37.5 \%$ responses. $25 \%$ of the respondents are of opinion that lack of technical manpower is another reason of dissatisfaction, followed by social media services should be on chargeable mode. Ahenkorah-Maefo and Akussah (2016) also depicted in their study that there is a lack of required skills among the respondents to use social media as tool for delivery of library services. Agyekum, Beatric and Trivedi (2016) suggested that the libraries should be provided with Internet connectivity and other necessary tools to ensure proper functioning and effective usage of networking tools. Butt, Qutab and Mohamad (2011) examined the 48 academic libraries (university and college), 21 special libraries, 5 public libraries and 1 school library in the city of Lahore. The results showed that the major problem in access and use of the Internet was the slow speed of the Internet faced by $48 \%$ libraries. The second major problem faced by $32 \%$ libraries was connection cutoff and $31 \%$ libraries faced the problem of shortage of funds. The staff members as well as users in $27 \%$ libraries were not aware of the advantages to use of Internet. The study showed that libraries under study had inadequate hardware facility, unavailability of support to maintain the Internet facility and limited time for users to access the Internet. Tripathi and Kumar (2010) conducted a study on use of social networks in libraries of higher education institutions. The results of study show that social network has the capacity to improve library services to the users. The study put forward the suggestions for library and information science professionals to adopt social media for delivery of traditional services in an innovative manner to address the information requirements of the users of ICT based era.

\section{Conclusion}

The present study has concentrated on the frequent users of social media in medical colleges of Punjab i.e. the librarians. The scope of the study was limited to the medical colleges of Punjab only. There is a vast scope for future research in different settings, on various types of users, activities and comparison of users' performance and attitudes towards the social media.

The study concluded that librarians of medical colleges should be trained on social media applications for better and timely exchange of medical information resources to medical teachers and students for better healthcare services in the Punjab State.

\section{References}

1. Ayu, A. R., and Abrizah, A. Do you Facebook? Usage and applications of Face book pages among academic libraries in Malaysia. Int Inf Libr Rev 2011;43(4):239-249. http://doi:10.1080/105 72317.2011. 10762906.

2. Agyekum, B. O., Beatric, A., Trivedi, M. Adoption of social networking tools in public university libraries in Ghana. Int J Innov Res dev, 2016;5(5): Retrieved from http://www.ijird.com/index.php/ijird/article/viewFile/92261/68 680 (ISSN) 2278-0211.

3. Ahenkorah-Maefo, M., and Akussah, H. Changing the face of reference and users services: Adoption of social media in top Ghanaian academic libraries. Reference services Review 2016;44(3):219-236. http://doi:10.1108/ RSR-01-2016-0001.

4. Butt, K., Qutab, S., and Mohamad, K. (2011). Access and use of the internet in the libraries of Lahore Pakistan.Chines Librarianship. Int Electron $J$ 31. Retrieved from http://www.iclc.us/cliej/ c131BQM.pdf.

5. Mansor, Y. and Idris, S. (2010). Perception, awareness and acceptance of library 2.0 applications among librarians at the international Islamic university Malaysia. Webolog 7 (2): Retrieved from http://www.webology.org/2 010/v7n2/a81.html.

6. Tripathi, M, and Kumar, S. (2010). Use of web 2.0 tools in academic libraries: A reconnaissance of the international landscape. Int Inf Libr Rev 2010;42(3):195-207. http://doi:10.1080/1057 2317.2010.10762864.

How to cite this article: Kaur S, Manhas R, Awareness, knowledge, attitude and use of social media among librarians and in libraries of medical colleges of punjab: A study, Indian J Libr Sci inf techno.2018;3(2):70-73 